Людмила БАБЮК,

orcid.org/0000-0002-0112-6700

аспірантка кафедри історії і культури Украӥни

ДВНЗ «Переяслав-Хмельнииький

державний педагогічний університет

ім. Григорія Сковороди»

(Украӥна, Переяслав-Хмельницький) valeriy.n12@gmail.com

\title{
ПРОСТИТУЦІЯ В РАДЯНСЬКІЙ УКРАЇНІ ЯК СОЦІАЛЬНЕ ЯВИЩЕ (1921 - 1927 рр.)
}

\begin{abstract}
Розглядається розвиток проституиії як соиіального явища на території Радянської України у роки Нової економічної політики (НЕПу) у 1921 - 1927 рр. Особлива увага зосереджена на поширені проституції, з'ясуванні основних причин та особливостей. Розкриті ключові заходи радянської влади, спрямовані на викорінення проституиіі та перевиховання повій. Названі основні відомства, які брали участь у боротьбі з проституцією. Виокремлені особливості роботи у цьому напрямі. На основі аналізу джерел та історіографічної бази встановлено наслідки поширення проституції $і$ з'ясовані результати боротьби з нею.
\end{abstract}

Ключові слова: НЕП, проституція, повії, жінка, венеричні захворювання, міліиія, жінвідділи. Лim. 12.

Ludmyla BABIUK, postgraduate student, Department of history and culture of Ukraine, «Pereiaslav-Khmelnytskyi Hryhoriy Skovoroda State Pedagogical University» (Ukraine,Pereiaslav-Khmelnytskyi)valeriy.n12@gmail.com

\section{PROSTITUTION IN SOVIET UKRAINE AS A SOCIAL PHENOMENON (1921 - 1927)}

The article deals with the development of prostitution as a social phenomenon on the territory of Soviet Ukraine during the years of the New Economic Policy (NEP) from 1921 to 1927. The purpose of the study was to reveal the main causes of the peculiarities of spreading measures of counteraction and consequences of prostitution in the Ukrainian SSR during the years of the NEP. Among them, it is worth highlighting a low standard of living, unemployment, low qualifications of women. Special attention is focused on the spread of prostitution, the explanation of the main causes and characteristics. The key measures of soviet power, aimed at eradicating prostitution and reeducation of prostitutes, are disclosed. The main departments that participated in the fight against prostitution are accentuated. The features of work in this direction are singled out. On the basis of analysis of sources and historiographical base, the consequences of the spread of prostitution and the results of the struggle with it are found.

The article discusses the main measures to combat prostitution including: advocacy, show trials, the organization of conferences, meetings, lectures, formation of special committees, the establishment of labor colonies for prostitutes and involvement of law enforcement agencies to raids. The first years of NEP policies were characterized by uncertainty about "flesh trade», resulting in a soft policy towards rehabilitation of prostitutes. The basic directions of propaganda against prostitution are revealed. Identified features of organizational and legislative measures aimed at combating this phenomenon. Detected criminal component prostitution and uncovered the role of police in exposing the "dens of debauchery». The prostitute's position regarding the criminal code of the USSR is determined. The main methods of rehabilitation of prostitutes are revealed: from public condemnation to the formation of 
labor colonies. The status of the prostitutes in the period of unrolling the NEP and the transition to the administrative-command system is determined.

Key words: NEP, prostitution, prostitutes, woman, venereal diseases, measures, militia, departments of women.

Ref. 12.

Людмила БАБЮК, аспирантка кафедры истории и культуры Украины ДВНЗ «Переяслав-Хмельницкий государственный педагогический университет им. Григория Сковородьı»

(Украина, Переяслав-Хмельниикий) valeriy.n12@gmail.com

\section{ПРОСТИТУЦИЯ В СОВЕТСКОЙ УКРАИНЕ КАК СОЦИАЛЬНОЕ ЯВЛЕНИЯ (1921 - 1927 ГГ.)}

Рассматривается развитие проституциии как социиального явления на территории Советской Украины в годы Новой экономической политики (НЭПа) в 1921 - 1927 гг. Особое внимание сосредоточено на распространении проституции, выяснении основных причин и особенностей. Раскрыты ключевые мероприятия советской власти направленные на искоренение проституции и перевоспитания проституток. Перечислены основные ведомства, участвовавшие в борьбе с этим явлением. Выделены особенности работы в этом направлении. На основе анализа источников и историографической базы установлены последствия распространения проституции и выяснены результаты борьбы с ней.

Ключевые слова: НЭП, проституция, проститутки, женщина, венерические заболевания, милиция, женотдел.

Лит. 12.

Постановка проблеми. У роки незалежності України постала проблема створення механізму регулювання суспільної моралі, яка запобігатиме виникненню таких негативних явищ, як злочинність, проституція, безпритульні діти та інше. Особливе місце зайняла проблема росту проституції, а відтак досить важливим залишається вивчення історії зародження цього негативного явища та вивчення досвіду боротьби з ним. Враховуючи той факт, що особливий розвиток проституції розпочався після встановлення більшовиками радянської влади, дослідження цієї проблеми у роки Нової економічної політики (НЕП) є актуальним у наш час.

Розкриття причин, особливостей розвитку, основних заходів боротьби та наслідків проституції на території Радянської України в роки НЕПу є головною метою статті.

Аналіз новітніх досліджень. Розвиток проституції у революційний період та в роки НЕПу є досить складною проблемою, оскільки важко зробити висновки стосовно масовості цього негативного явища. Радянські дослідники замовчували поширення цього явища на території Радянського Союзу або ж зазначали, що його рівень значно знизився у зв'язку з гендерною політикою більшовиків. Зокрема, А. Малахов у «Три века российской проституции» зазначав, що скасування грошей під час революції, заміна вінчання на «червоне весілля», пропаганда вільного кохання склало значну конкуренцію для проституції [4]. 3 позицією А. Малахова не погоджується В. Суховий, зазначаючи, що інформація радянського дослідника має пропагандистський характер. Більше того, він наводить факти, які свідчать про зростання проституції у період НЕПу [9].

Окремі аспекти розвитку антисоціальних явищ серед жінок розкриті у дисертаційній роботі О. О. Коханової. У ній розглядаються основні причини розвитку проституції у період НЕПу [3]. Серед них виділяються низький рівень соціального забезпечення жінок, складна економічна ситуація та нехтування релігійною мораллю.

Особливості боротьби проти проституції відображено у працях В. А. Греченко [2], О. А. Міхеєва [5], А. О. Ришкова [7]. Вони висвітлювали основні методи протидії поширенню цього негативного явища, зокрема показові суди, пропаганда, організація лекцій, з’їздів та облави. 
Виклад основного матеріалу. Радянська влада, проголосивши мету сформувати новий образ вільної жінки, проводила активну пропагандистську політику. Водночас, спроби трансформації свідомості жіноцтва України мали не лише позитивні, але й негативні наслідки, до яких варто віднести проституцію.

Складна економічна ситуація, негативні наслідки воєнних дій, голод та заперечення християнської моралі більшовиками стали основними причинами зростання проституції в містах України на початку 1920-х рр. Якщо в дореволюційний період стримуючим фактором росту аморальності була церква та громада, то з приходом більшовиків з їх антирелігійною та гендерною політикою відбулися суттєві зміни у регламентації суспільних відносин. Відповідно цей фактор став певним каталізатором розвитку проституції, що особливо помітно проявлявся на початок НЕПу. Саме в цей період, через складну соціальну ситуацію, безробіття жінки шукали способи прогодувати себе та своїх дітей $[3,94]$. У документах НКВС УСРР зазначалося, що рівень проституції зростав не лише серед безробітних та безпритульних жінок, але й серед робітниць, які використовували це заняття як додатковий заробіток $[9,71]$.

Дослідник Греченко В.А. стверджує, що у результаті проведеного опитування у 1924 р. було визначено, що 47,9 \% повій із 642 причиною свого заняття назвали злидні, а 31\% - займалися проституцією заради легких грошей. Це пояснюється двома чинниками: перший - появою багатих непманів, що збільшило попит на «жриць кохання»; другий - низьким рівнем кваліфікації жінок їх безробіття, і як наслідок - зростала кількість повій [2, 23].

Реальний рівень проституції у роки НЕПу визначити досить складно через низку об'єктивних факторів, а саме: 1) складно визначити кількість будинків розваг та повій, які в них працювали; 2) фактично неможливо визначити точну кількість жінок, які працювали не в будинках розваг, тобто займалися додатковим заробітком [5, 64].

Враховуючи наявні дослідження цієї проблеми, варто виокремити такі різновиди проституції: професійна, трудова, допоміжна, дитяча, кримінальна [8]. Відповідно до різновиду, можна визначити основні причини, зокрема: професійна - жінки, які продавали власне тіло за покликанням; трудова - «продажна любов», спричинена безробіттям; допоміжна - як додатковий заробіток, зумовлений нестачею коштів на проживання; дитяча - спричинена безпритульністю серед дітей; кримінальна - розповсюджена у злочинних притонах.

Позиція радянської влади стосовно «продажної любові» довгий час лишалася невизначеною. На початку 1920-х рр. основним принципом запобігання розвитку цього явища в Радянській Україні став принцип «Боротьба з проституцією, а не з повією». Однак він не був втілений на практиці, і після проголошення НЕПу був згорнутий $[2,24]$. Варто зазначити, що радянська влада явище проституції називала своєрідним рудиментом чи пережитком капіталізму, а відтак окремого правопорушення за торгівлю тілом не передбачалося $[9,72]$. Таким чином, $з$ початком Нової економічної політики виникла необхідність формування нових основ боротьби з проституцією та іiі наслідками.

Радянська влада, розуміючи негативні наслідки від розвитку проституції, сформувала систему заходів, а саме: показові суди, пропаганда, організація конференцій, нарад, лекцій, створення спеціальних комісій, трудових колоній для жінок та залучення правоохоронних органів до облав.

Пропагандистські заходи, зокрема, публічні дискусії на сторінках періодичних видань, показові суди, лекції мали на меті розкрити явище проституції як негативний пережиток капіталізму, де, на думку партійного керівництва та жіночих організацій, чоловіки ставилися до жінки як до речі $[12,19-22]$. Відповідно у статтях пропагандистського характеру на цьому наголошувалося. Водночас, у загальних періодичних та жіночих виданнях проводилися дискусії на тему проституції та заходів боротьби з нею. Зокрема, з ініціативи ЦК КП(б)У на початку 1920-х рр. проведено низку таких публічних обговорень $[11,63]$. Щоправда, дискусії зводилися здебільшого до цитування основної лінії боротьби з цим антисоціальним явищем та пропаганди комуністичної партії, як головної рушійної сили в боротьбі з проституцією.

Розвиток проституції на території Радянської України в роки НЕПу (1921 - 1927) став підгрунтям для появи низки інших проблем, зокрема поширення венеричних хвороб. Відтак Наркомати охорони здоров'я та соціального забезпечення у першій половині 1920-х рр. звернули 
помітну увагу на цю проблему [7, 164]. Зокрема, з їх ініціативи спільно з жінвідділом ЦК КП(б)У було сформовано Інститут братів і сестер соціальної допомоги, завданням якого була допомога, жінкам, які виявилися у скрутному становищі та заробляють за рахунок продажу свого тіла [11, 44-45].

Радянська влада влаштовувала лекції на тему венеричних захворювань та проблеми проституції, у загальних та жіночих журналах друкувалися статті, роздавалися листівки та інше. Зокрема, торгівля тілом на початку 1920-х рр. вважали у контексті «паразитичної нетрудової» діяльності $[9,73]$. У періодичних журналах повій досить часто зображували у неприглядному вигляді: вимучена постать зі штучною усмішкою на обличчі та яскравим макіяжем, одягнена у вульгарний одяг, хвороблива. Такий образ мав відлякувати жінок від цієї професії. Подавався образ сутенера, який б'є, гвалтує повії та відбирає у них гроші. Автори пропонували альтернативу жінкам - лікування у медичних закладах та працевлаштування на виробництво. Однією з проблем, яку зачіпали автори таких творів, - це дитяча проституція. Зокрема, вони наголошували на основних причинах іiі, a також зазначали, що подолати це явище можливо лише шляхом ліквідації безпритульності $[1,46]$.

Серед заходів боротьби з проституцією пропагандистського характеру радянська влада використовувала показові суди. Зокрема, жінвідділ ЦК КП(б)У, за дорученням Всеукраїнського центрального виконавчого комітету (ВУЦВК), розробила спеціальний сценарій такого суду, у якому показували аморальну, асоціальну поведінку проститутки [12, 16-17].

На засіданні Колегії жінвідділу ЦК КП(б)У 17 січня 1921 р. порушувалося питання стосовно боротьби з проституцією та наслідками цього явища. Враховуючи швидке поширення венеричних хворіб, проблема набирала республіканського значення, а відповідно для її розв'язання залучалися інші відомства, у тому числі при Наркоматі охорони здоров’я УСРР (НКОЗ). Відповідно, у його структурі було сформовано Комісію, яка виконувала завдання профілактики та лікування венеричних хвороб, а також вела просвітницьку роботу серед жінок, з метою недопущення «продажної любові» на виробництві $[11,2-3]$. Тим не менш, значних результатів не було досягнуто, у зв'язку з низьким рівнем життя та соціального забезпечення жіноцтва.

У роки НЕПу радянська влада проводили низку організаційних заходів боротьби 3 проституцією, зокрема з ініціативи М. Скрипника, за підтримки жінвідділу ЦК КП(б)У, було створено міжвідомчу комісію. До ії складу увійшли представниці жіночого відділу, Південного бюро Всесоюзної центральної ради професійних спілок (ВЦРПС), НКОЗу, Народного комісаріату освіти (НКО), Наркомсоцбезу, Наркомюсту, Наркомпраці, Народного комісаріату внутрішніх справ, Главкомпраці. Завданням комісії стала комплексна розробка законодавчих заходів боротьби з проституцією [11, 21-22]. Вона, зокрема, розробляла комплекс заходів, а потім, через губернські та жіночі відділи, втілювали їх у практичне життя $[9,72]$.

Члени Комісії називали проституцію «трудовим дезертирством», а тому передусім вважали за необхідне, щоб держава надавала робітницям соціальну допомогу та підтримку. Вважалося, що жінка, яка мала повне матеріальне забезпечення, не буде шукати інших варіантів для заробітку, а відтак поступово відпаде потреба у «продажній любові». Члени Комісії пропонували створювати трудові колонії, у яких жінки з асоціальною поведінкою поступово вливатимуться у суспільне життя [12, 19-22]. Однак ідею створення таких колоній не було реалізовано на практиці до другої половини 1920-х рр. Лише у жовтні 1927 р. при Дніпропетровському окружному диспансері було створено перший та єдиний на території УСРР трудовий профілакторій для повій, який проіснував до кінця 1920-х рр. [6, 40].

Комісія з боротьби проти проституції проіснувала менше року. Вже 21 листопада 1921 р. ï̈ було ліквідовано рішенням ЦК КП(б)У у зв’язку з недостатньо проведеною роботою [11, 71]. Тим не менше, відомства, які входили до складу Комісії продовжували роботу у цьому напрямі, зокрема НКОЗ УСРР проводив лікування, облік та профілактику венеричних захворювань, НКО УСРР - пропагандистсько-освітні заходи, Наркомюст - юридично координував боротьбу з проституцією, НКВС - здійснював облік та облави, жінвідділи - координували просвітницьку роботу серед жінок.

Ліквідація Комісії викликала невдоволення серед партійних активісток. Зокрема, вони вважали такі дії недоцільними, оскільки для координації роботи, спрямованої на викорінення про- 
ституції як асоціального явища у радянському суспільстві, необхідна спеціальна інституція, яка об'єднає всі відомства та ресурси $[11,75]$.

Водночас, Наркоматом соціального забезпечення УСРР та Наркоматом охорони здоров'я (НКОЗ) УСРР здійснювалася діяльність, спрямована на ліквідацію різних суспільних хвороб, у тому числі проституції [7, 164]. Так, при НКОЗ УСРР на початку 1920-х рр. було організовано центральну раду для боротьби з соціальними хворобами та проституцією. Вона розробляла заходи, які згодом впроваджували у життя губернські ради для боротьби 3 венеризмом і проституцією. Особливого значення набули такі заходи, як надання венерологічним клінікам статусу диспансерну, рекомендації для підприємств стосовно скорочення штатів, особливо жіночого персоналу, розробка заходів підвищення кваліфікації жінок, боротьба з жіночою та дитячою безпритульністю, надання жінкам роботи та житла тощо [9, 73-74].

У 1923 р. НКОЗ УСРР видав «Положення про губернські ради по боротьбі з венеризмом і проституцією», який регламентував втілення заходів боротьби з проституцією, венеричними хворобами на безпосередньо місцевих рівнях. Губернські ради організовували лікувально-трудові профілакторії, призначені для обслуговування безробітних жінок, хворих на венеричні захворювання. Представниці жінвідділів, які входили до складу рад, відповідали за проведення кампанії проти проституції, зокрема організовували облави на будинки розпусти [10, 81].

Губернські ради здійснювали контроль за дотриманням 10 \% броні для жінок на виробництві. Відповідно їхні представники проводили перевірки на підприємствах з метою встановлення кількості працюючих жінок та їхнього матеріального забезпечення, а також проводили облік хворих $[6,35]$. Проведення цих заходів на місцях зумовило поступове зниження рівня захворюваності венеричними хворобами, а також знизило кількість повій. Тим не менше, на середину 1920-х рр. проблема проституції в УСРР не була подолана радянською владою.

На початку 1923 р. голова ВУЦВК Г. І. Петровський та Нарком охорони здоров’я М. Г. Гуревич, у зв'язку зі зростанням рівня проституції, звернулися до губвиконкомів та губздороввідділів з циркуляром, у якому зазначалася необхідність викорінення проституції на території УСРР. У ньому зазначалися заходи, на які мали спиратися місцеві виконкоми, ради та підприємства, зокрема: 1) при скорочені штатів обережно ставитися до самотніх жінок, безпритульних дівчат, вагітних та жінок з малими дітьми; 2) відділи охорони здоров'я передовсім повинні захищати інтереси найуразливіших категорій жіноцтва; 3) створити промислові артілі з метою забезпечення жінок робочими місцями; 4) посилення професійної роботи серед жінок; 5) проведення агітаційної кампанії, спрямованої на дискредитацію проституції та висвітлення її як ганебного явища $[2,29-30]$.

У 1925 р. у Харкові відбувся II Всесоюзний з'їзд по боротьбі з венеричними захворюваннями. Його учасники дійшли до висновку, що задля зниження кількості хворих необхідно провести активні заходи, спрямовані на боротьбу з проституцією, яка є основним джерелом походження цих хвороб $[6,39]$. Так, якщо у першій половині 1920-х рр. заклади охорони здоров'я не мали права проводити примусові медичні огляди повій (дозволялося лише клієнтів будинків розпусти, яких викрила міліція), то вже у другій половині 1920-х рр. лікувальні заклади мали право проводити примусову перевірку, у разі підозри на захворювання [6, 39].

Більшість повій були безпосередньо пов'язані зі злочинністю, а відтак ними цікавилися не лише лікувально-профілактичні та соціальні заклади, жінвідділи, але й органи НКВС УСРР. Варто зазначити, що у Кримінальному кодексі УСРР 1922 р. не було ніяких настанов стосовно оцінки проституції, а відтак жінки за ці діяння не несли відповідальності. Влітку 1922 р., зважаючи на зростання потоку голодуючих біженок, що зумовив загострення проблеми проституції, НКВС розробив та опублікував проект «міліції моралі», а також запропонував висилати повій до Сибіру у спеціальні колонії з метою їх перевиховання. Проте через обурення та критику зі сторони керівництва жіночих організацій він не був реалізований [2, 26-27]. Крім того, представники НКВС у першій половині 1920-х рр. здійснювали реєстрацію повій, публічних будинків та хворих [11, 20].

У 1924 р. НКВС видав «Інструкцію органам міліції УСРР про боротьбу з проституцією», у якій зазначалося, що повій можна притягнути лише як свідків для розкриття злочинів, пов'язаних iз сутенерством, звідництвом, утриманням кубел розпусти та ін. [2, 26]. На практиці працівники 
міліції досить часто використовували повій не лише у розшуковій роботі, але й для відкриття будинків розпусти, де вони самі були активними споживачами «продажної любові». Згідно з виданою інструкцією, органи НКВС мали виявляти підпільні «кубла розпусти», а відтак здійснювати спостереження, постійні перевірки та облави на повій. Досить часто самі «жриці кохання» ставали агентами у викритті сутенерів та публічних будинків [2, 30]. Проте всі ці дії мали узгоджуватися з місцевою радою та місцевими жінвідділами КП(б)У.

У таємному циркулярі НКВС УСРР від 25 вересня 1925 р. зазначалося, що помірковані заходи боротьби з проституцією не давали значних результатів, а тому необхідно шукати нових, більш ефективних методів $[2,28]$. Відповідно перед правоохоронними органами постало завдання проводити облік усіх повій, а також спостереження за місцями, де ймовірно існувало «кубло розпусти». Це означало, що з середини 1920-х рр. радянська влада розпочала боротьбу з проституцією, яка мала масовий і суспільний характер $[9,74]$.

У другій половині 1920-х рр. органи НКВС отримали розпорядження діяти активніше у боротьбі з проституцією. Зокрема, враховуючи той факт, що рівень «продажної любові» з середини 1920-х рр. не знизився, радянська влада заявила про необхідність ізоляції повій від суспільства, а також використання їх на виробництві. Керівництво УСРР відзначено, що проститутки за своєю соціальною природою не здатні до перевиховання, а тому до них необхідно застосовувати нетрадиційні методи впливу. Відтак, відбулося повернення до проектів НКВС УСРР стосовно жорстких заходів проти проституції, які не були реалізовані у першій половині 1920-х рр. У 1926 р. НКВС розробив проект стосовно залучення повій до трудової повинності, шляхом ізоляції їх у трудових колоніях Сибіру $[2,28]$. У зв'язку з низкою обставин проект не вдалося реалізувати, однак він свідчить про радикально жорстоке ставлення органів влади до проблеми проституції і шляхів ії подолання.

У момент згортання НЕПу та переходу до командно-адміністративної системи управління, радянська влада розпочала ще жорсткіший наступ на проституцію. Фактично це явище було прирівняне до небезпечного, антисоціального злочину, за який винні мали нести кримінальне покарання $[2,76]$.

Висновки. Таким чином, у роки НЕПу рівень у Радянській Україні проституції зростав у зв'язку з безробіттям, низьким рівнем життя жіночого населення, значною кількістю безпритульних дівчат, становище погіршилося через голод 1921 - 1923 рр. Однією з ключових причин аморальної поведінки окремих жінок та становленням їх на шлях повії стало нехтування християнською мораллю, у результаті більшовицького антирелігійного наступу. Враховуючи високий рівень проституції у період НЕПу, який спричинив поширення венеричних захворювань, радянська влада здійснила низку заходів з метою викорінення цього явища. У першій половині 1920-х pp. вони мали більш рекомендаційний, пропагандистський характер. Профілактичні заходи зосереджувалися на проведенні лекцій, з'їздів, влаштуванням на виробництво жінок. Зважаючи на низькі результати, у другій половині 1920 -х рр. органи НКВС розпочали карні заходи з метою викриття не лише «кубел розпусти» та сутенерів, але й обліку повій, а згодом, в умовах згортання НЕПу, їх арештовували.

\section{СПИСОК ВИКОРИСТАНИХ ДЖЕРЕЛ І ЛІТЕРАТУРИ}

1. Адамська I. Г. Медико-санітарна пропаганда в УСРР у 1920-х роках / I. Г. Адамська // Гілея. К., 2015. - Вип. 93. - С. 44-48.

2. Греченко В. А. Боротьба міліції з проституцією в УСРР у добу НЕПу / В. А. Греченко // Вісник ХНУВС. - Харків, 2015. - № 1 (68). - С. 22-33.

3. Коханова О. О. Суспільно-політичне становище жінки в радянській Україні / О. О. Коханова // дис. канд. іст. наук: 07.00.01. - Харків, 2015. - 208 с.

4. Малахов А. Три века российской проституции / А. Малахов. - [Електронний ресурс]. - Режим доступу: www.aferizm.ru/histiry / his_3_veka rus_prost.htm

5. Міхєєва О. Кримінальна злочинність і боротьба з нею в Донбасі $(1919$ - 1929). - Донецьк, 2004. $248 \mathrm{c}$.

6. Мовчан О. Медичне обслуговування робітників УСРР. 1920-ті pр. / О. Мовчан // Проблеми історії України: факти, судження, пошуки. - 2006. - № 15. - С. 19-64. 
7. Ришкова А. О. До історії створення Народного комісаріату соціального забезпечення УСРР / А. О. Ришкова // Вісник Харківського національного університету ім. В. Н. Каразіна. - Харків, 2009. № 852 . - C. $160-167$.

8. Сидоренко А. О. Формування радянського менталітету засобами масової культури в УСРР в роки НЕПу / А. О. Сидоренко // [Електронний ресурс]. - Режим доступу: http://zv.refik.in.ua/udk-94-477-19211928a-o-sidorenko/index.html

9. Суховий В. І. Заходи органів місцевої влади по боротьбі з проституцією на Катеринославщині-Дніпропетровщині у міжвоєнні роки / В. І. Суховий // Придніпров'я: історико-краєзнавчі дослідження. - Дніпропетровськ, 2009. - Вип. 9. - С. 68-76.

10. Турчіна М. О. Медичне законодавство в Україні в Радянський період / М. О. Турчіна. - Дис. канд. ю. наук: 12.00.01. - Харків, 2015. - 223 с.

11. Центральний державний архів громадських об’єднань України (далі - ЦДАГО). - Ф. 1. - Оп. 20. Спр. 818. - 121 арк.

12. ЦДАГО. - Ф. 1. - Оп. 20. - Спр. 824. - 88 арк.

\section{REFERENCES}

1. Adamska I. H. Medyko-sanitarna propahanda v USRR u 1920-kh rokakh / I. H. Adamska // Hileia. K., 2015. - Vyp. 93. - S. 44-48.

2. Hrechenko V. A. Borotba militsii z prostytutsiieiu v USRR u dobu NEPu / V. A. Hrechenko // Visnyk KhNUVS. - Kharkiv, 2015. - № 1 (68). - S. 22-33.

3. Kokhanova O. O. Suspilno-politychne stanovyshche zhinky v radianskii Ukraini / O. O. Kokhanova // dys. kand. ist. nauk: 07.00.01. - Kharkiv, 2015. - $208 \mathrm{~s}$.

4. Malakhov A. Try veka rossyiskoi prostytutsyy / A. Malakhov. - [Elektronnyi resurs]. - Rezhym dostupu: www.aferizm.ru/histiry / his_3_veka rus_prost.htm

5. Mikhieieva O. Kryminalna zlochynnist i borotba z neiu v Donbasi $(1919-1929)$. - Donetsk, 2004. $248 \mathrm{~s}$.

6. Movchan O. Medychne obsluhovuvannia robitnykiv USRR. 1920-ti rr. / O. Movchan // Problemy istorii Ukrainy: fakty, sudzhennia, poshuky. - 2006. - № 15. - S. 19-64.

7. Ryshkova A. O. Do istorii stvorennia Narodnoho komisariatu sotsialnoho zabezpechennia USRR / A. O. Ryshkova // Visnyk Kharkivskoho natsionalnoho universytetu im. V. N. Karazina. - Kharkiv, 2009. - № 852. S. $160-167$.

8. Sydorenko A. O. Formuvannia radianskoho mentalitetu zasobamy masovoi kultury v USRR v roky NEPu / A. O. Sydorenko. - [Elektronnyi resurs]. - Rezhym dostupu: http://zv.refik.in.ua/udk-94-477-19211928-a-o-sidorenko/index.html

9. Sukhovyi V. I. Zakhody orhaniv mistsevoi vlady po borotbi z prostytutsiieiu na Katerynoslavshchyni-Dnipropetrovshchyni u mizhvoienni roky / V. I. Sukhovyi // Prydniprovia: istoryko-kraieznavchi doslidzhennia. - Dnipropetrovsk, 2009. - Vyp. 9. - S. 68-76.

10. Turchina M. O. Medychne zakonodavstvo v Ukraini v Radianskyi period / M. O. Turchina. - Dys. kand. yu. nauk: 12.00.01. - Kharkiv, 2015. $-223 \mathrm{~s}$.

11. Tsentralnyi derzhavnyi arkhiv hromadskykh obiednan Ukrainy (dali - TsDAHO). - F. 1. - Op. 20. Spr. 818. -121 ark.

12. TsDAHO. - F. 1. - Op. 20. - Spr. 824. -88 ark. 